Marek Mariusz Tytko ${ }^{1}$

Uniwersytet Jagielloński w Krakowie

\title{
OTWARCIE NA WIARE W FILOZOFICZNO-PEDAGOGICZNEJ KONCEPCJI STEFANA SZUMANA
}

\section{Openness to Belief in the Thinking of Stefan Szuman}

Summary: 1. The goal of this article is to present the openness to belief in Stefan Szuman's thinking. 2. Methodology. The author uses the historiographical method. 3. The main results of the analysis. The author discusses the following philosophical (metaphysical and ethical) and pedagogical (educational) issues: the virtue of belief (the virtue of faith) and the non-virtue of atheism (the un-virtue of atheism), and Szuman's arguments concerning, among other things, the relation between man and God, the relation between belief (faith) and reason, and the relations of human rights to belief (faith) and to salvation. Quotations for the analysis have been taken from Szuman's published works, written before, during or after World War II. The author also presents the influence of Szuman's ideas on Karol Wojtyła (1920-2005), who was a participant in his 1949 university seminar on philosophical anthropology (i.e.: "characterology," or personalism) at the Jagiellonian University in Krakow. 4. Limitations of the analysis. This article encourages further discussion of the place of belief (faith) in the Humanities, albeit the discussion is limited to the ideas of Stefan Szuman. 5. Practical implications. The results of the analysis may be used as a rational argument for the greater presence of belief (faith) in the Humanities. 6. Social implications. The results of the analysis are of value to teachers. 7. The originality of the article (new value, novelty). The paper is the first to present a primary source and example-based discussion of Stefan Szuman's ideas regarding belief and openness to God.

${ }^{1}$ Dr n. hum. Marek Mariusz Tytko jest nauczycielem akademickim Biblioteki Jagiellońskiej Uniwersytetu Jagiellońskiego w Krakowie, afiliowanym do Wydziału Zarządzania i Komunikacji Społecznej UJ w Krakowie. Adres: Biblioteka Jagiellońska UJ, al. Mickiewicza 22, 30-059 Kraków; e-mail: marek.mariusz.tytko@uj.edu.pl. 
Ke y w ord s: Stefan Szuman (1889-1972), belief, faith, creed, philosophy of being, metaphysics, ethics, philosophy of culture, human nature, pedagogy, belief and reason, virtue, non-virtue (un-virtue), atheism, Jagiellonian University, Krakow, conscience, personalism, human rights, Christianity, culture, man, God, Absolute, human dignity, John Paul II (1978-2005), Karol Wojtyła (1920-2005), Zygmunt Mysłakowski (1890-1971), communism in Poland.

\section{Wstęp}

Tekst jest oryginalnym przyczynkiem, opartym na źródłach. Celem autora jest przedstawienie fragmentu koncepcji pedagogiczno-antropologicznej Stefana Szumana dotyczącej otwarcia na wiarę w Boga w kontekście epoki. Tekst powstał przy użyciu historiograficznej metody analizy dokumentów. O metafizycznej, religijnej postawie Szumana przed II wojną światową napisał Kazimierz Czachowski (1936) w swojej historii literatury polskiej, streszczając opinię na temat poezji Łukasza Flisa (pseudonim Stefana Szumana), którą opublikował przedwojenny krytyk literacki Karol Wiktor Zawodziński, autor z kręgu Skamandra (1934²): „nawet wytrawny i wymagający krytyk poetów Karol W[iktor] ${ }^{3}$ Zawodziński umiał dostrzec we Flisie [S. Szumanie - M.T.] poetę-filozofa poświęcającego się »zagadnieniom metafizycznym i religijnym [...]«"4.

Poza tym jednym zdaniem, nikt z badaczy kwestiami wiary lub Boga u Szumana nie zajmował się w ogóle od ponad osiemdziesięciu lat (1936-2017), stąd niniejszy tekst stanowi próbę wypełnienia białej plamy w badaniach „szumanologicznych", które w zasadzie nie istnieją w tytułowym zakresie.

2 Autor niniejszego artykułu odnalazł wymienioną recenzję Karola Wiktora Zawodzińskiego. Por. Karol Wiktor Zawodziński, „Liryka”, Rocznik Literacki 1933 [wyd. 1934], 14-47. Recenzja na temat książki Stefana Szumana, pseud. Łukasz Flis, pt. „Drzwi uchylone”, 1933 (1932), znajduje się tam na s. 37. Ważna uwaga dotycząca przedruków recenzji Karola Wiktora Zawodzińskiego. Zob.: Karol Wiktor Zawodziński, Wśród poetów, oprac. Wanda Achremowiczowa, wstęp Jerzy Kwiatkowski (Kraków: Wydawnictwo Literackie 1964), XV, 432, [1]. Indeks (tamże, 1964) - n i e w y ka zuj e ani nazwiska, ani pseudonimu autora "Drzwi uchylonych", mimo że pozycja ta (1964) zawiera przedruki przedwojennych recenzji krytyka Karola Wiktora Zawodzińskiego. Oznacza to najpewniej, że komunistyczne Wydawnictwo Literackie nie chciało w żaden sposób promować nazwiska Stefana Szumana oraz jego przedwojennych poezji metafizycznych i religijnych (1933). To bardzo znamienne w kontekście nieco wcześniejszej odmowy przez to samo Wydawnictwo Literackie druku Szumanowej książki pt. Natura, osobowość i charakter człowieka, napisanej w latach 1940-1943. Jak można było wymazywać Szumana z pamięci, to czyniono to konsekwentnie.

${ }^{3}$ Wszelkie dopowiedzenia, uwagi, pytania pochodzące od autora niniejszego artykułu, w cytowanych, cudzych wypowiedziach, ujęto w nawisy kwadratowe [ ] dla odróżnienia od tekstu cytowanego.

${ }^{4}$ Por. Kazimierz Stanisław Czachowski, Obraz współczesnej literatury polskiej 1884-1933, t. 3: Ekspresjonizm i neorealizm (Lwów: P.W.K.S. 1936), 518. Tomy 1-3 wydano w latach 1934-1936. O Stefanie Szumanie w t. 3 krytyk ten napisał na stronach 518-521, 523, 526, 604. Tu cytat ze s. 518. 


\section{Otwarcie na wiarę w pismach naukowych i filozoficznych Stefana Szumana}

Przez termin „otwarcie na wiarę" rozumie się w niniejszej pracy następujący desygnat: pozytywne odniesienie do wiary, przy zachowaniu jednoczesnej postawy rozumnej (be z negacji rozumu), czyli traktowanie wiary jako niezbędnego dopełnienia poznania rozumowego. Autor niniejszego tekstu ma świadomość, że „otwarcie rozumu na wiarę" nie jest tym samym, co „fideizm”, aczkolwiek za Powszechna encyklopedia filozofii (2002) można przyjąć następujące wyjaśnienie: „fideizm pojmowany jako dopełnienie poznania rozumowego jest możliwy do przyjęcia"s.

Postawa otwartości na Transcendencję okazuje się istotna dla wychowania, a zwłaszcza dla wychowania przez sztukę, wychowania przez piękno, wychowania do piękna, wychowania w pięknie (w ramach pedagogiki kultury), gdzie czynnik pozaracjonalny (uczuciowy) nie jest do końca uchwytny rozumowo (przeżycie piękna sztuki), dlatego że z istoty rzeczy dzieła sztuki (arcydzieła) powstają także przy udziale czynnika pozarozumowego, ponieważ „natchnienie" piękna ma charakter transcendentny; na ten temat por. pogląd Szumana z 1937 roku: „piękno spływa jak Duch Święty”.

Inną jeszcze kwestią jest Bóg jako Gwarant dobra, prawdy i piękna, co także ma swoje bezpośrednie przeniesienie na kwestię wychowania przez piękno sztuki, również w koncepcji Szumana.

Sama filozofia (na przykład antropologia) nie wyjaśnia sensu istnienia człowieka, ponieważ sens bycia człowiekiem leży poza nim samym, dopiero teologia wskazuje na transcendentne źródło sensu istnienia (człowieka czy świata) oraz na źródło racjonalności wszechświata i racjonalności człowieka. Odnalezienie sensu istnienia w koncepcji Szumana prowadzi ku teologii, teologia bowiem daje naturalne uzasadnienie Szumanowej filozofii, choć tenże uczony teologią nie zajmował się wcale, lecz co najwyżej sugerował, gdzie należy szukać sensu istnienia człowieka, czy lepiej: gdzie należy szukać gwarancji dla sensu istnienia człowieka (tenże krakowski profesor niedwuznacznie wskazywał na Boga), stąd „otwarcie na wiarę” („teologizm”) był spójnym elementem poglądów Szumana na sens istnienia człowieka czy wszechświata. Omawiany tu krakowski teoretyk pedagogiki sprzeciwiał się traktowaniu religijności jako instynktu (podobnie jak i przeżyć sztuki), ponieważ przeżycia religijne nie należą do biologii ${ }^{7}$, oraz w żadnym

${ }^{5}$ Czesław Bartnik, Zdzisław Chlewiński, „Fideizm”, w: Powszechna encyklopedia filozofii, t. 3: E-G, (Lublin: Polskie Towarzystwo Tomasza z Akwinu 2002), 427-429. Cytowane fragmenty zostały opracowane przez Zdzisława Chlewińskiego.

${ }^{6}$ Stefan Szuman, „Wstęp zasadniczy do zagadnień wychowania estetycznego”, Marchołt. Kwartalnik poświęcony sprawom literatury i kultury 3 (1936/1937): 318.

7 Tenże, „Instynkty u człowieka”, Kwartalnik Pedagogiczny. Organ Sekcji pedagogicznej Stowarzyszenia Chrześcijańsko-Narodowego Nauczycielstwa Szkót Powszechnych 1 (1934): 23. 
wypadku nie umniejszał znaczenia religijności człowieka, lecz - przeciwnie o religii pisał pozytywnie jako o drodze do afirmacji życia: „Przeżycia transcendentalne, religijne możliwe są do zrealizowania, a więc realne tylko o tyle, o ile wywierają wpływ na sposób życia i tworzą z nim harmonijną całość".

Szuman jako konsekwentny realista w zakresie filozofii bytu (czyli metafizyki), przestrzegał jednak dalej przed jałowymi, abstrakcyjnymi „przeżyciami metafizycznymi", oderwanymi od realnego istnienia, które nie służą człowiekowi w znalezieniu sensu życia i przynoszą skutek odwrotny od zamierzonego: „Wszelkie natomiast przeżycia metafizyczne, które właściwemu, realnemu, indywidualnemu życiu odbierają jego [życia - M.T.] własny i immanentny sens, paraliżują zdrowy zmysł życia".

Wymienione powyżej, „metafizyczne”, jałowe przeżycia należałoby w Szumanowej koncepcji połączyć z tym, co określał on jako „martwa, czysto racjonalistyczna koncepcja Absolutu, który indywidualność pochłania jak otchłań” ${ }^{10}$.

Krakowski profesor widział negatywny wpływ tak filozoficznie (po Heglowsku) ujętego Absolutu na świadomość człowieka i nie zalecał tej drogi w życiu. Martwy Absolut nie jest właściwie Absolutem, nie jest w ogóle Bogiem, lecz tylko wymyśloną przez człowieka fikcją filozoficzną, co powodować może negatywne nastawienie do życia u ludzi niewidzących sensu istnienia, ponieważ odrzucających taki pseudo-Absolut jako sens. Egzystencjalistycznie biorąc, Absolut filozofów jest martwy, dlatego że nie można z nim nawiązać relacji ludzkiej, osobowej, bezpośredniej, życiowej (nie ma mowy także o personalizmie), gdyż:

Odchodzimy coraz bardziej od prawdziwego życia, w miarę jak cel istnienia przesuwamy w transcendentalną rzeczywistość, w nieskończoność i wieczność, w której obliczu indywidualne, konkretne życie i działanie człowieka wydaje się czymś nieskończenie małym ${ }^{11}$.

Szuman jednak odróżniał'12 martwą koncepcję (martwego, nieosobowego) Boga filozofów od żywej koncepcji (żywego, osobowego) Boga religii. Według uczonego w żywym, głębokim, religijnym ujęciu Boga - Bóg jest Najwyższym Dobrem, w którym można partycypować w sposób autentyczny, po ludzku, czyli osobowo (personalizm). Szumanowe ujęcie żywego Boga wiary (religii) można

${ }^{8}$ Tenże, Afirmacja życia (Lwów: Lwowska Biblioteczka Pedagogiczna 1938), Seria: Licealna Biblioteczka Filozoficzna, t. 12, 18.

9 Tamże.

${ }^{10}$ Tamże, 22.

11 Tamże.

12 Tamże, 22-23. Rzecz charakterystyczna, cytat pochodzi z roku 1938, a w kolejnym wydaniu Afirmacji życia ten sam tekst włączony w całość dzieła pt. Poważne i pogodne zagadnienia afirmacji życia (1947) został okrojony przez cenzurę (lub autocenzurę) tak, iż passus o martwym Absolucie filozofów i żywym Bogu wiary nie znalazł się w tekście. Zob. Stefan Szuman, Poważne i pogodne zagadnienia afirmacji życia (Katowice: Józef Nawrocki 1947), 134. 
tu zinterpretować jako Osobę (Najwyższe Dobro Osobowe), z którą osoba ludzka (człowiek) wchodzi w relację uczuciową i poprzez emocjonalną, mistyczną wspólnotę następuje osiągnięcie celu życia, to jest „afirmacja życia”, gdyż Szuman bardzo przychylnie odnosił się do relacji człowieka z żywym Bogiem wiary. Jego zdaniem taka postawa to „uczuciowe, głębokie ujęcie nieskończoności, mistyczne zjednoczenie z Najwyższym Dobrem"13.

W powyższym opisie Szumana (pochodzącym z 1936 i 1938 roku, przedrukowanym $\mathrm{z}$ istotnymi zmianami w $1947 \mathrm{roku}$ ) wyraźnie dostrzec można sformułowany wprost personalizm: communio, więc zjednoczenie z Bogiem Życia. Egzystencjalistyczny rys człowieka cechował się więc w Szumanowej koncepcji już w latach trzydziestych odcieniem personalistycznym: człowiek jest to homo religiosus, wierzy w życie i Dawcę życia. Ów personalistyczny wątek został zmieniony nieco za sprawą cenzury lub autocenzury (1947). To, co ocalało i było nową redakcją tekstu w stosunku do roku 1938, brzmiało następująco (1947 - tekst zmieniony):

Człowiek transcenduje w swym umyśle realnie dotąd poznaną rzeczywistość i szuka najogólniejszych celów istnienia i bytu, snując koncepcje religijne i metafizyczne. Nie każda metafizyka jest absurdem i urojeniem. Każda z poważnych, religijnych czy filozoficznych koncepcyj metafizycznych jest próbą myślowego rozwiązania zagadki bytu, w ten sposób, by w zakresie takiej koncepcji życie ludzkie mogło się przedstawić jako (istotny) sens posiadające ${ }^{14}$.

Widać więc pewien kompromis, na przykład z Heglowskim absolutem ${ }^{15}$, w powojennej, zmienionej redakcji przedwojennego tekstu Szumana (1947). W każdym razie słowo „Bóg” w powojennych tekstach publikowanych za życia S. Szumana zniknęło w zasadzie całkowicie za sprawą cenzury komunistycznej (zakazane dyskursy). Jakkolwiek uczony wprost deklarował jeszcze w 1947 roku: „Wrogiem wszelkiej metafizyki nie jestem”" Sędzia Sprawiedliwy pojawił się dopiero w pośmiertnie wydanym dziele życia pt. Natura, osobowość i charakter człowieka (1995), napisanym przez Szumana w latach 1940-1943, którego druku odmówiły mu dwukrotnie w okresie PRL-u wydawnictwa, między innymi powołane przez komunistów w 1953 roku Wydawnictwo Literackie w Krakowie.

Trzeba mieć na względzie to, jak bardzo komunizm w Polsce wypaczył polską pedagogikę i historię polskiej pedagogiki, skutki czego odczuwamy do dziś. Po II wojnie rozpoczęło się odsuwanie od wpływów wybitnych intelektualistów

13 Szuman, Afirmacja, 22-23.

14 Tenże, Poważne, 131-132.

${ }^{15}$ Jest rzeczą trudną do ustalenia, czy zmiana tekstu nastąpiła pod wpływem czynników zewnętrznych (presja komunistycznej cenzury), czy też zmiana miała charakter autonomiczny, w wyniku zmiany zapatrywań Szumana, piastującego wówczas godność Dyrektora Państwowej Wyższej Szkoły Pedagogicznej w Krakowie (1946-1948).

${ }^{16}$ Szuman, Poważne, 8. 
przedwojennych i następowała "produkcja” nowej, tak zwanej inteligencji socjalistycznej, również w pedagogice na zasadzie doboru negatywnego. Prawdziwy autorytet, wybitny polski uczony, prof. dr fil. i med. Stefan Szuman, major Wojska Polskiego, bohater wojny polsko-bolszewickiej 1920 roku, uczestnik wojny obronnej we wrześniu 1939 roku, oficer Związku Walki Zbrojnej i Armii Krajowej w latach 1940-1945, członek dowództwa Batalionu AK „Skała” (1944), w czasie II wojny prowadzący $z$ narażeniem życia tajne nauczanie i aresztowany przez Niemców, także w okresie powojennym był represjonowany, inwigilowany przez komunistyczne, sowieckie służby Urzędu Bezpieczeństwa Publicznego / Służbę Bezpieczeństwa (1945-196917) i został przez komunistów odsunięty od nauczania w UJ za głoszone, niezależne poglądy (1950-1957).

Szuman był katolikiem od swego chrztu (1889) aż do swojej śmierci (1972) i bronił wiary chrześcijańskiej, a każdy a teizm nazywał wprost nie cnotą. W swojej tak zwanej charakterologii Natura, osobowość $i$ charakter człowieka (1940-1943, wydanej pośmiertnie w 1995 roku przez krakowskie Wydawnictwo Apostolstwa Modlitwy - Księży Jezuitów), Stefan Szuman pisał wprost o „otwarciu na wiarę" (wierze w Boga jako jedynego Dawcy sensu życia ludzkiego): „[...] wierzymy, że Bóg odda w końcu każdemu sprawiedliwość. Bez tej wiary istnienie nasze byłoby pozbawione sensu"18.

Nadto uczony ten realistycznie wskazywał w cytowanym dziele między innymi na to, że: „Żyjemy [...] zgodnie z zasadami jakiegoś wyznania lub ruchu pozawyznaniowego" ${ }^{19}$, a jednocześnie pisał o „cnocie pobożności i niecnocie bezbożności”20.

To jasno i wyraźnie hierarchizuje zasady życia według wiary (religii) wyżej aniżeli zasady życia według negatywnego $\mathrm{z}$ gruntu ateizmu (etymologicznie: $a$-Theo, bez Boga), stąd tu niecnota „bezbożności”, tj. niecnota ateizmu (ateizm z gruntu jest owocem demoralizacji duchowej, błędem poznawczym i grzechem, jeśli się świadomie odrzuca istnienie Boga).

Szuman kwestię postawy religijnej w życiu człowieka widział ewolucyjnie, ponieważ, według tegoż uczonego, wraz z upływem czasu zmieniają się zapatrywania człowieka, na przykład co do możliwości poznania Boga.

17 Instytut Pamięci Narodowej - Komisja Ścigania Zbrodni przeciwko Narodowi Polskiemu - Oddziałowe Biuro Udostępniania i Archiwizacji Dokumentów w Krakowie, teczka S. Szumana, sygnatura: IPN Kr 010/5529.

18 Stefan Szuman, Natura, osobowość i charakter człowieka, przedmową opatrzyły: Grażyna Czyżewicz, Zofia Skórzyńska (Kraków: Wydawnictwo WAM Księża Jezuici 1995), 203. Uwaga: dzieło to pod tymże samym, identycznym tytułem $z$ adnotacją „dotąd nie publikowane (w rękopisie)" zostało wzmiankowane publicznie już jako istniejące w bibliografii jednej z książek S. Szumana w 1947 roku. Zob. tenże, Psychologia wychowawcza wieku szkolnego. Podręcznik dla nauczycieli i studentów (Kraków: Wiedza. Zawód. Kultura. Księgarnia. Wydawnictwo. Skład Nut 1947), 298, Literatura do rozdziału XIV, poz. 5.

19 Szuman, Natura, 212.

20 Tamże, 205-206. 
„Byt, Istnienie, Świat, Dusza, Bóg”21 człowiekowi w życiu wydają się kolejno: 1. całkowicie poznawalne (gdy jest dzieckiem), 2. tylko częściowo poznawalne (gdy dorasta), 3. całkowicie niepoznawalne jako tajemnica (gdy jest już dojrzały). W tak zarysowane odnośniki do Boga wpisał się egzystencjalizm Szumana jako $\mathrm{w}$ gruncie rzeczy egzystencjalizm wiary, egzystencjalizm nadziei i egzystencjalizm miłości. Wiara w życie budzi nadzieję na znalezienie sensu życia po to, by przez miłość do życia stać się w pełni człowiekiem. Powyższe trzy dobra (trzy cnoty Boskie, tak zwane cnoty teologalne), uznawał Szuman, oprócz między innymi duchowości, za cnoty najważniejsze dla człowieka (razem uczony ten wymieniał siedem cnót).

Szuman wiarę w Boga i wiarę w Byt łączył w jedno, nie byłoby bowiem istnienia (Stworzenia), gdyby nie było Boga (Stwórcy), inaczej mówiąc: istnienie stanowi dowód, że Bóg istnieje, dlatego afirmacja istnienia (życia) jest jednocześnie afirmacją Boga. Kwestia człowieka w oderwaniu od kwestii Boga nie ma sensu w Szumanowej koncepcji. Bóg i człowiek połączeni są osobową relacją miłości czy też zaufania (personalizm), a Bóg okazuje się Gwarantem wszelkich dóbr dla człowieka. Gdyby nie było Boga, nie byłoby fundamentu transcendentaliów, o które tak upominał się Szuman (Prawdy, Dobra i Piękna), a więc pośrednio także wychowanie przez sztukę / wychowanie przez piękno nie miałyby sensu, bo nie byłyby ugruntowane na pewnym fundamencie istnienia dóbr, fundamencie gwarantowanym przez Boga, Który Jest. Przypomnieć trzeba, że Stefan Szuman był klasykiem polskiej pedagogiki, a nie tylko „ostatnim klasykiem polskiej psychologii” (jak go nazywano już po jego śmierci). Okazuje się również wybitnym klasykiem polskiej pedagogiki kultury (z pierwszego pokolenia polskich pedagogów kultury), co wciąż nie dociera do świadomości wielu polskich pedagogów lub bywa rugowane z tej świadomości. Szuman prawdę, dobro i piękno jako podstawy pedagogiki kultury opierał na Prawdzie, Dobru i Pięknie, które wszak są tylko wieloma imionami Boga, o czym nie należy zapominać (zob. Pseudo-Dionizy Areopagita). Krakowski profesor napisał wszak wprost na temat wiary i braku wiary oraz ich konsekwencji:

Mówiąc o wierze[,] mam na myśli przede wszystkim niezbędne w życiu zaufanie do istnienia, choć nie przeczę, że sprowadza się ono [zaufanie - M.T.] w rezultacie do pokładania ufności w Bogu. [...] Każda wiara jest antropocentryczna: jest wiarą nie tylko w Boga, ale i w człowieka, wiarą w obowiązek szukania prawdy, jak też w prawo człowieka do znalezienia jej [prawdy - M.T.] i do zbawienia. Wiarę nazwałem zaufaniem do istnienia, bo jest ona [wiara - M.T.] czymś więcej niż przekonaniem o istnieniu Boga - jest także wiarą w godność ludzką. Natomiast koncepcja bytu bez dobrego i sprawiedliwego Boga jest równocześnie koncepcją człowieka jako istoty pozbawionej wyjątkowego sensu swego istnienia ${ }^{22}$.

\footnotetext{
21 Szuman, Poważne, 14.

22 Tenże, Natura, 205.
} 
Ks. Karol Wojtyła (1920-2005), późniejszy papież Jan Paweł II (1978-2005), najwybitniejszy uczeń Stefana Szumana, uczestnik jego seminariów, słuchał w jednym roku Stefana Szumana na ostatnim w UJ prowadzonym przezeń seminarium (1949) z zakresu antropologii filozoficznej, tj. charakterologii, czyli personalizmu (jak nazywał swoją "charakterologię" tenże uczony).

Warto także nadmienić na marginesie, że w roku 1949 po raz ostatni pozwolono Szumanowi wykładać na ówczesnym Wydziale Humanistycznym UJ, następnie w 1950 roku (podobnie jak Roman Ingarden) został przez komunistów odsunięty od zajęć ze studentami pod tym pretekstem, że miał on jakoby „szkodliwy wpływ na młodzież” (to oczywiście sfingowany zarzut, zupełnie bezpodstawny, chodziło o to, że nie był on ateistą, marksistą, komunistą, członkiem partii komunistycznej lub jej zwolennikiem). Stefan Szuman w UJ od 1928-1939 i od 1945 do 1949/1950 jawnie nauczał kolejne roczniki przyszłych nauczycieli, zatem miał on rzeczywisty wpływ na kształtowanie prawidłowych postaw setek przyszłych polskich wychowawców, dlatego komuniści pozbawili go możliwości zajęć ze studentami (1950-1957), a następnie wbrew woli tegoż uczonego, mimo podpisanej z nim kilkuletniej umowy, wysłali go przedwcześnie na przymusową emeryturę (1960), oparłszy się na nowych zarządzeniach komunistycznego ministerstwa.

Uczeń Szumana ks. Karol Wojtyła, już jako Jan Paweł II, mówił podczas pierwszej pielgrzymki do Polski (1979) znane powszechnie słowa, które weszły już do kanonu polskiej humanistyki, a które kontynuowały i rozwijały w sposób oczywisty wcześniejszą, cytowaną powyżej, myśl Szumana, z którą Wojtyła zapoznał się podczas jego seminariów charakterologicznych w UJ w 1949 roku:

Człowieka bowiem nie można do końca zrozumieć bez Chrystusa, a raczej człowiek nie może siebie sam zrozumieć bez Chrystusa. Nie może zrozumieć, ani kim jest, ani jaka jest jego właściwa godność, ani jakie jest jego powołanie i ostateczne przeznaczenie. Nie może tego wszystkiego zrozumieć bez Chrystusa. I dlatego Chrystusa nie można wyłączać z dziejów człowieka w jakimkolwiek miejscu ziemi ${ }^{23}$.

Szuman zaś expressis verbis pisał ponadto o prawie do wiary i prawie do zbawienia, które przysługują każde mu człowiekowi na równi $\mathrm{z}$ innymi prawami, a może nawet bardziej przed innymi prawami, ponieważ człowiek jest $\mathrm{z}$ natury homo religiosus. Krakowski profesor nie wskazał na konkretną wiarę (religię, konfesję), na przykład katolicką, prawosławną, protestancką czy też islam lub judaizm. Jego koncepcja otwarcia na wiarę w szerszym ujęciu mogłaby się odnosić zasadniczo do każdej wiary monoteistycznej, gdyż pisał o Bogu, a nie

${ }^{23}$ Jan Paweł II, Homilia na Placu Zwycięstwa, Warszawa, 2 czerwca 1979 roku (odnośny fragment, film), https://www.youtube.com/watch?v=A3eN9xMSuxc (dostęp: 9.03.2017). Odnośny tekst (fragment): http://www.zrodlo.krakow.pl/rocznik-2011/numer-18/czlowieka-nie-mozna-do-konca-zrozumiec-bez-chrystusa/ (dostęp: 9.03.2017). 
o bogach (politeizm). Z kontekstu można jednak wnioskować pośrednio, że chodzi tylko o chrześcijański monoteizm, a nie o judaizm czy islam. Szuman zaliczał wiarę do cnót, a jej siłą jest wzmacnianie godności człowieka (wyróżnienia pochodzą od Szumana - w oryginale to podkreślenia): „Wiara w wieczność jest jednocześnie wiarą w ludzką godność. [...] Cnota wiary jest ufnością i w tym leży jej [cnoty wiary - M. T.] siła"24.

W koncepcji Szumana wiara w osobowego Boga i wiara w osobową godność człowieka łączyły się ze sobą (ta druga wynikała z tej pierwszej), a ostatecznym celem (przeznaczeniem) stawała się wieczność. Podobne zestawienie pojawiło się później w cytowanej już wypowiedzi Jana Pawła II (1979), w której podkreślał on, że człowiek bez Boga (bez Chrystusa): „nie może zrozumieć, ani kim jest, ani jaka jest jego właściwa godność, ani jakie jest jego powołanie i ostateczne przeznaczenie" 25 .

Jednocześnie Szuman piętnował ateizm (bezbożność) jako błędną filozofię podcinającą zaufanie człowieka do istnienia, do bytu i pozbawiającą człowieka fundamentu wartości (dóbr) - Boga (ateizm jest błędem poznawczym i błędem antropologicznym).

Przez bezbożność rozumiem to, co słowo to oznacza dosłownie: czyli życie bez Boga i wyobrażanie sobie bytu pozbawionego pierwiastków dobroci, sprawiedliwości, prawdy i miłości. [...] Światopogląd materialistyczny, nie uznający transcendentnego sensu świata i nie biorący pod uwagę ponadspołecznych, metafizycznych i moralnych, a w najwyższym stopniu ludzkich zobowiązań, tęsknot i nadziei, nie prowadzi do wiary, bo nie wzmacnia zaufania do bytu ${ }^{26}$.

W podobnym do Szumana duchu jednoznacznej dezaprobaty dla ateizmu i materializmu przemawiał Jan Paweł II (1979) w cytowanym już fragmencie wypowiedzi o tym, że człowiek: „nie może tego wszystkiego zrozumieć bez Chrystusa. I dlatego Chrystusa nie można wyłączać z dziejów człowieka w jakimkolwiek miejscu ziemi" ${ }^{27}$.

Szuman swoją dezaprobatę wobec ateizmu (niewiary) wyrażał jeszcze mocniej w następujących słowach: „niewiara podkopuje samo życie”, dlatego nie może być mowy o ateizmie czy marksizmie w jego filozofii życia. Przestrzegał też przed ateistycznym bożkiem - „społeczeństwem”, które zajęło (jako produkt liberalnej lub komunistycznej ideologii ateistycznej) miejsce Boga usuniętego przez ateizm wraz z religią. Tymczasem, dla porównania, w ateistycznej, lewicowej koncepcji Herberta Reada „bożkiem” stało się „społeczeństwo”, przed którego

\footnotetext{
24 Szuman, Natura, 205.

25 Jan Paweł II, Homilia na Placu Zwycięstwa.

26 Szuman, Natura, 205.

27 Jan Paweł II, Homilia na Placu Zwycięstwa.

28 Szuman, Natura, 206.
} 
deifikacją (gloryfikacją) tak przestrzegał polski uczony. Trzeba tu wyraźnie powiedzieć, że Szuman nie ostrzegał przed "narodem”, który uznał (podobnie jak teoretycy narodowi) za naturalny twór kulturowy (wynikający z prawa naturalnego, łac. ius), lecz przestrzegał przed „społeczeństwem”, które jest tworem sztucznym, budowanym nienaturalnie na mocy ideologii, tak zwanej umowy społecznej (czyli de facto - narzuconego odgórnie projektu), czyli sztucznego, uchwalanego arbitralnie prawa pozytywnego (łac. lex), bo wbrew kulturze narodowej, pisał on bowiem wprost: „Ateizm racjonalistyczny zdetronizował boga mitologicznego, filozoficznego i mistycznego - potrzebnego ludziom uczuciowo i dla zrozumienia sensu istnienia - a postawił na opróżnionym piedestale nowe bóstwo: społeczeństwo"29.

Tym samym krakowski uczony stanął na przeciwnym stanowisku niż marksizm (czy socjologizm), na przykład Herberta Reada, który „społeczeństwo” ujmował jako cel $\mathrm{w}$ wychowaniu człowieka. Jednocześnie trzeba tu podkreślić, że Szuman przez powyższą krytykę ateizmu czy „społeczeństwa” wpisał się w tradycję polskiej, katolickiej myśli narodowej (Teodor Tomasz Jeż, Bogdan Jański, Liga Narodowa, Stanisław Prus-Szczepanowski ps. „Piast”, świekr S. Szumana, spoczywający na lwowskim Cmentarzu Łyczakowskim ${ }^{30}$, ponadto Stanisław Łempicki, Zygmunt Balicki, Lucjan Zarzecki, Kazimierz Brodziński, Jan Ludwik Popławski, Roman Dmowski oraz inni). Nie dziwi to, zważywszy na patriotyczne poglądy obecne w czynach i pismach członków rodziny Szumanów i Szczepanowskich. Stefan Szuman był zięciem wymienionego powyżej Stanisława Prusa-Szczepanowskiego, ojca polskiej myśli narodowej. Także przedwojenni personaliści polscy (na przykład Karol Górski, Bilans bezbożnictwa) krytykowali ateizm jako przyczynę zła (totalitaryzmu, komunizmu) w świecie, więc Szumanowa krytyka również została wpisana i w ten nurt personalistyczny wolnej, niepodległej, suwerennej Polski międzywojennej, wprowadzającej katolickie zasady społeczne w czyn (Konkordat 1925).

Według Szumana człowiek w Bogu znajduje rzeczywistą dobroć i sprawiedliwość, rzeczywistą prawdę i miłość. Transcendentalny sens świata gwarantuje w konsekwencji immanentny sens istnienia. Zobowiązania metafizyczne,

29 Tamże, 217.

30 Stanisław Prus-Szczepanowski (zmarły w 1899 roku) został pochowany na Cmentarzu Łyczakowskim we Lwowie, obecnie nr kwatery (czyli „pola”): pole 1B, blisko wejścia głównego po lewej stronie. Obecna numeracja ukraińska (XXI wiek) jest nieprzydatna w poszukiwaniu grobu-monumentu, ponieważ numeracja ta nie zachowuje podziału na rzędy i numery mogił (co ułatwiałoby odszukanie). Pomnik Stanisława Prusa-Szczepanowskiego jest okazały, wyróżnia się od otoczenia, wyrasta ponad inne mogiły. Informacja o numerze kwatery uzyskana przeze mnie od doc. dr Magdaleny Smoczyńskiej (córki Jerzego Turowicza, krewnej Szumanów) w maju 2005 r. Pomnik S. Prusa-Szczepanowskiego powstał jako dzieło artysty Grzegorza Kuźniewicza. Fotografia pomnika Stanisława Prusa-Szczepanowskiego i opis znajdują się w książce autorstwa Stanisława S. Niciei. Por. Stanisław S. Nicieja, Cmentarz Łyczakowski we Lwowie w latach 1786-1986, (Wrocław: Zakład Narodowy im. Ossolińskich 1988), 172-173. Por. także wydanie drugie, rozszerzone. 
zobowiązania moralne i zobowiązania ponadspołeczne prowadzą do Boga. Tęsknoty metafizyczne, tęsknoty moralne i tęsknoty ponadspołeczne również wiodą do Boga. Nadzieje metafizyczne, nadzieje moralne i nadzieje ponadspołeczne prowadzą także do Boga. Wszystkie te tęsknoty, nadzieje i zob ow i ą z a n i a wzmacniają w człowieku zaufanie, czyli wiarę w istnienie. Szumanowa filozofia życia w świetle jego otwarcia na wiarę (teocentryzmu, teologizmu) nabrała wymiaru uniwersalistycznego. Sens życia został podbudowany sensem istnienia, a ten z kolei ufundowany jest w Najwyższym Sensie, którym jest Bóg. Bóg jako osobowy Sens nad sensami, osobowe Piękno nad pięknami, osobowe Dobro nad dobrami, osobowa Prawda nad prawdami pozostaje istotny i konieczny w koncepcji Szumana, gdyż bez Boga transcendentnego byt i dobra głębszego (a nawet: żadnego) sensu nie mają i wtedy na próżno trudzą się różni „uczeni”, lecz Boga nie da się niczym zastąpić, to znaczy nic nie zastąpi Boga, dosłownie: nic (nihilizm także nie).

Szuman, podobnie jak św. Tomasz z Akwinu (uznający wiarę i rozum za autonomiczne władze człowieka, łac. fides et ratio), wyraźnie jednak rozdzielał zagadnienia wiary od zagadnień wiedzy, lecz to dzięki wierze otwierają się człowiekowi oczy na inny niż materialny wymiar rzeczywistości. Dzięki wierze człowiek może "przejrzeć". Wiara staje się mądrością znajdującą sens życia w tajemnicy transcendentnej, dokąd wiedza dotrzeć nie może z powodu braku narzędzi badawczych umożliwiających „zbadanie” Boga, dlatego uczony krakowski rozdzielał (pisząc to w latach 1940-1943) porządek objawienia od porządku wiedzy:

[...] wiara nie jest wiedzą. Jest raczej mądrością, która ma zaufanie do dna tajemnicy i do istnienia sensu życia, choćby mu [istnieniu? sensowi? życiu? - M.T.] nieustannie zaprzeczał pozorny bezsens. [...] Inną rzeczą jest dowiedzieć się a inną pr zejr zeć wiarą. [...] Wiara nie jest niczym innym jak nadzieją i miłością prawdy - jest przeżyciem mistycznym. [...] Tylko wiara jest naprawdę życiodajna -niewiara podkopuje samo życie. [...] Cnota wiary jest cechą dojrzałego charakteru. Człowiek dojrzały wierzy[,] [...] umacnia się $\mathrm{w}$ tej cnocie [...] przez duchowe, mistyczne pogłębienie samego siebie ${ }^{31}$.

Wiara okazuje się dobrem - a jako dobro jest przeżywana, ponieważ każde dobro człowiek przeżywa, choć w różnym stopniu, inaczej mówiąc: dobro nieprzeżyte przez osobę nie byłoby jego dobrem (uwewnętrznionym, czyli zinternalizowanym). Wiara jako miłość prawdy, czyli wiara jako wielka namiętność duchowa do prawdy, i wiara jako nadzieja prawdy - oto są Szumanowe interpretacje chrześcijańskich trzech cnót teologalnych: wiary, nadziei i miłości, ujętych w kontekście prawdy, rozumianej jako prawda objawiona, a nie tylko jako zgodność poznania z rzeczywistością (klasycznie u św. Tomasza z Akwinu, łac.: „veritas est

\footnotetext{
31 Szuman, Natura, 206.
} 
adaequatio rei et intellectus" ${ }^{32}$ ), jak to się dzieje w poznaniu ludzkim (na przykład $\mathrm{w}$ nauce). Szuman w swoim otwarciu na wiarę, moim zdaniem, sięgał de facto także do rozważań kardynała Henry’ego Newmana o relacjach wiedzy i wiary, lecz krakowski teoretyk rozwijał wątki powyższe po swojemu, inspirując się koncepcją rozdzielenia, uzupełnienia wzajemnego tych dwóch sfer kultury. Szuman nigdy nie przeciwstawiał sobie wiedzy i wiary, lecz traktował je jako komplementarne sfery ludzkiej kultury. Podobny ton komplementarności wiedzy i wiary (mający wspólne ugruntowanie w pismach św. Tomasza $\mathrm{z}$ Akwinu) znalazł się w - ogłoszonej ćwierć wieku po śmierci Szumana - encyklice Fides et ratio Jana Pawła II, który jako młody ks. dr Karol Wojtyła był, jak już wspomniano, pół wieku wcześniej uczestnikiem seminariów z zakresu antropologii filozoficznej i personalizmu, podczas których Szuman czytał na głos bardzo obszerne fragmenty maszynopisu jego własnej, niewydanej za swego życia, książki pt. Natura, osobowość i charakter człowieka, napisanej w latach 1940-1943, a przepisanej w całości w 1943 roku na maszynie przez jego córkę, Grażynę Szumanównę ${ }^{33}$.

Według ujęcia Stefana Szumana źródłem wiary jest Bóg, lecz nie byłoby wiary w Boga, gdyby nie trwoga (Kierkegaardowska trwoga egzystencjalna), która skłania człowieka ku Bogu. Krakowski uczony zdał sobie sprawę z tego warunku wiary, kiedy zapisał następujące słowa: „Bez lęku przed tajemnicą człowiek nigdy nie odkryłby wieczności. Męstwo zapewnia wieczność - ale odkrywa ją właśnie odwieczny, metafizyczny, ludzki lęk"34.

Personalistyczny egzystencjalizm Szumana wyrastał więc z metafizyczności lęku przed tajemnicą (łac. tremendum fascinans), tak jak w koncepcji Rudolfa Otto.

Z drugiej strony lęk zostaje przezwyciężony świętością, która niesie z sobą najwyższy wymiar szczęścia i najwyższy wymiar wszelkiej wartości (najwyższy wymiar wszelkiego dobra). Krakowski profesor pisał o świętości uczuć (na przykład miłości), świętości przeżycia czy świętości życia ludzkiego między innymi następujące słowa: „Dar życia staje się świętym” ${ }^{35}$, „całe prawie życie może być przepojone świętością" ${ }^{36}$.

W takim kontekście otwarcie na wiarę nabiera znaczenia w wychowaniu, bo u polskiego teoretyka filozofia życia obejmuje całe życie we wszystkich aspektach,

32 Św. Tomasz z Akwinu napisał w swoim korespondencyjnym ujęciu prawdy, że: „Veritas est adaequatio intellectus et rei”. Pełny cytat: „Cum enim veritas intellectus sit adaeqatio intellectus et rei, secundum quod intellectus dicit esse quod est vel non esse quod non est” (Thomae, Summa contra gentiles, I, 59; por także: Thomae, De veritate 1,1).

33 Grażyna Szuman (1923-2015), od sierpnia 1945 - Grażyna Czyżewiczowa, zamężna ze Zbigniewem Czyżewiczem - porucznikiem Armii Krajowej, aresztowanym w Krakowie i więzionym przez około pół roku przez Sowietów, wywiezionym do łagru w Związku Sowieckim już po zniewoleniu Polski przez Rosję Sowiecką (1945).

${ }^{34}$ Szuman, Natura, 208.

35 Tamże, 233.

36 Tamże, 232. 
czyli w wychowaniu i sztuce także. Dla Szumana, doktora medycyny, świętość życia ludzkiego, od naturalnego poczęcia do naturalnej śmierci, była czymś oczywistym, niepodlegającym dyskusji.

Świętość, według Szumana, jest immanentna w człowieku, ponieważ świętość zostaje wlana w ludzką duszę jako dana przez Boga człowiekowi. Argumentem przemawiającym za powyższym rozumieniem świętości okazuje się istnienie w duszy ludzkiej (immanentnie) Głosu Bożego, który przemawia z głębi sumienia w jaźni człowieka (wewnątrz jaźni istnieje sumienie, wewnątrz sumienia dusza, wewnątrz duszy - istota człowieczeństwa, w istocie człowieczeństwa jest Głos Boga, wzywający do Dobra, Prawdy, Piękna). Powyższa Szumanowa koncepcja zgadzała się z biblijną koncepcją stworzenia człowieka na obraz i podobieństwo Boże, ponieważ Bóg przebywa we wnętrzu każdego człowieka jako Głos wzywający do dobra (miłości). Uczony krakowski odmawiał rozumowi wglądu w świętość, ponieważ to już sfera wiary nie do zrozumienia: „A rozum nie może więcej powiedzieć o świętości, niż to, że ją w duszy ludzkiej zastaje, i to, że jej nie rozumie, ponieważ rozum rozeznaje tylko zewnętrzne fakty i ich związki, ale nie potrafi ocenić ich duchowej wartości" ${ }^{37}$, a więc dóbr stojących za tymi faktami. Z powyższego stanowiska uczonego widać, że Szuman uzasadnił nieracjonalność rozumu, kiedy tenże rozum wykracza poza swoje kompetencje i zajmuje się sferą, której racjonalnie zrozumieć się nie da, gdy się nie uwzględni wiary. Powyższe stwierdzenie ma także swoje dalsze konsekwencje w wychowaniu przez sztukę, ponieważ w wypadku na przykład dzieł religijnych, działających na wychowanka - nie da się racjonalnie wyjaśnić (gdy pomija się sferę wiary) fenomenu wpływu sztuki religijnej na człowieka. Nawrócenie przez sztukę (metanoia per artem) jest procesem występującym w większym stopniu u ludzi o usposobieniu wrażliwym na piękno, więc w konsekwencji antropologicznych założeń Szumanowych (tu: otwarcia na wiarę, teologizmu) pominąć się nie da przy rozważaniu jego koncepcji wychowania przez sztukę czy szerzej: jego pedagogiki kultury, której teoria wychowania przez sztukę stanowi nieodłączną część.

Wielka różnica zaistniała między koncepcjami Stefana Szumana teisty i Herberta Reada ateisty/agnostyka, więc u tego pierwszego mogły się pojawić w sposób naturalny rozważania o pięknie jako fascinans tremendum. Uczony krakowski wpisał się w tradycję rozumienia świętości ciągnącą się od Sørena Aabye’a Kierkegaarda przez Rudolfa Otto do Mircei Eliadego. Transcendentalia metafizyczne (piękno, dobro) i dobra szczegółowe (groza, świętość) są transcendentne względem człowieka i przerastają ludzkie możliwości rozumowe.

Świętość jest wartością [dobrem - M.T.] życia wewnętrznego człowieka, której rozum chciałby zaprzeczyć, ponieważ jest dla niego [rozumu - M.T.] nieuchwytna. Gdyby człowiek był istotą wyłącznie rozumną, a pozbawioną uczuć, nie mógłby przeżywać

37 Tamże, 233. 
wartości [dóbr - M.T.] tego, czego doświadcza, i nie wiedziałby nic ani o świętości, ani o dobroci, ani o potędze, ani o grozie i transcendencji istnienia. To, co piękne, dobre, straszne i święte przerasta tę rzeczywistość, którą rozeznajemy władzą rozumu ${ }^{38}$.

Wyraźnie antyoświeceniowe, postromantyczne stanowisko krakowskiego profesora w kwestii świętości i dóbr w ogóle jako transcendencyj (sic! - 1. mn.) bytu, stawia Szumana w opozycji do Johna Deweya, pragmatysty, który nie rozumiał transcendentnego doświadczenia, ponieważ był racjonalistą - pragmatykiem, stąd obce mu było transcendentalne rozumienie owych metafizycznych dóbr, które wykraczają poza doczesną rzeczywistość. W świetle (otwartej na wiarę) myśli polskiego uczonego o dobru doświadczenia koncepcja Deweya jawi się jako niepogłębiona, postoświeceniowa recepcja racjonalizmu. Szuman natomiast był religijnym teoretykiem kultury, ponieważ w homini religiosi upatrywał istotę mogącą tworzyć (współtworzyć, aktualizować) głęboką kulturę w pełni. Homo religiosus tworzy swój charakter i przez charakter moralny dochodzi do świętości. „Świętość urzeczywistnia się w charakterze”39.

$\mathrm{Na}$ tym zakończono analizę koncepcji Szumanowej na temat jego otwarcia na wiarę, zrekonstruowanej na podstawie wszystkich jego drukowanych dzieł naukowych i filozoficznych. Z nich „wyłuskano” wszystkie, bez wyjątku, wątki dotyczące wiary i zrekonstruowano jego „otwarcie na wiarę”.

W zestawieniu z publikacjami Zygmunta Mysłakowskiego, lansującymi od 1945 roku usilnie w Polsce sowiecką koncepcję a te ist yczn e go wychowania socjalistycznego (kolektywistycznego), trzeba stwierdzić, że ówczesne publikacje Szumana nie lansowały at eistycznej, kolektywistycznej koncepcji wychowania, lecz personalistyczną, co pośrednio także świadczy o otwarciu na wiarę (wierze w Boga). To wymowna różnica między dwoma pedagogami-profesorami z jednej uczelni.

Otwarcie na wiarę było jedną z najistotniejszych przesłanek Szumanowej koncepcji wychowania, która z pewnością nie miała na celu ani zsekularyzowanego humanizmu, ani agresywnego ateizmu realizującego ideologiczne, antyreligijne, antychrześcijańskie, antykatolickie cele w okresie panowania reżimu komunistycznego w Polsce (1939-1941 i od 1944 roku). To otwarcie na wiarę zapewne było przeszkodą, nie tylko w PRL-u, ale także i w okresie zeświecczonej „poprawności politycznej” w III Rzeczypospolitej Polskiej (post-PRL-u), skoro Szumanowe podstawowe dzieło pt. Natura, osobowość i charakter człowieka (napisane w latach 1940-1943) nie mogło zostać wydane przez żadne świeckie (państwowe lub prywatne) wydawnictwo już po okresie przemiany komunistycznego reżimu w inne, subtelniejsze formy panowania nad narodem polskim. Książkę wydali dopiero w 1995 roku księża jezuici w swoim Wydawnictwie Apostolstwa Modlitwy.

\footnotetext{
38 Tamże, 234.

39 Tamże, 235.
} 
Oczywiście, założone przez komunistów w 1953 roku Wydawnictwo Literackie nadal po 1989 roku nie było zainteresowane wydaniem książki Szumana (czyli nic się tu nie zmieniło, poza transformacją fasady i haseł). Znamienne, że nad tym dziełem (1995) w zateizowanych, postkomunistycznych mass mediach zaległa głucha cisza. Także w czasopismach naukowych III RP (nazywanej także PRL-em bis z racji braku dekomunizacji) nie ukazała się ani jedna recenzja z tego wybitnego dzieła Szumana, co okazuje się bardzo wymowne i nie wymaga szerszego komentarza poza jednym zdaniem (ujmując rzecz oględnie): widocznie niezależny umysł, klasyk pedagogiki, katolik i patriota polski Stefan Szuman jest nadal niewygodny pewnym, niezdekomunizowanym, wpływowym środowiskom naukowym, niechętnym lub nawet wrogim wierze i chrześcijaństwu w Polsce i przez milczenie wzmagają one niepamięć o tym wybitnym myślicielu polskim.

Szuman znał pisma św. Augustyna, który pisał, że kiedy Bóg jest na pierwszym miejscu, to wszystko jest na swoim miejscu. W Szumanowej koncepcji wychowania przez sztukę (szerzej: w jego pedagogice kultury i koncepcji pedagogiki w ogóle) wszystko jest na swoim miejscu, ponieważ Bóg jest na pierwszym miejscu.

Streszczeni e: 1 . Celem autora artykułu jest pokazanie otwarcia na wiarę w koncepcji Stefana Szumana. 2. Metodologia. Autor posłużył się historiograficzną metodą analizy dokumentu. 3. Główne wyniki analizy. Autor ukazuje następujące problemy filozoficzne (metafizyczne, etyczne) i pedagogiczne (wychowawcze): cnotę wiary i niecnotę ateizmu oraz argumenty Stefana Szumana dotyczące między innymi: relacji człowiek-Bóg, relacji rozumu i wiary, prawa człowieka do wiary i do zbawienia. Cytaty do analizy zaczerpnięto z publikowanych dzieł Szumana, zarówno tych pisanych przed wojną lub w jej trakcie, jak i opublikowanych po II wojnie światowej. Autor pokazał także wpływ pewnych pomysłów Stefana Szumana (1889-1972) na Karola Wojtyłę (1920-2005), uczestnika jego uniwersyteckiego seminarium z antropologii filozoficznej (tj. charakterologii, czyli personalizmu) w 1949 roku w Uniwersytecie Jagiellońskim w Krakowie. 4. Ograniczenia wyników analizy. Artykuł może być przyczynkiem do dyskusji nad miejscem wiary w humanistyce. Ograniczenia dotyczą odniesienia do koncepcji Stefana Szumana. 5. Implikacje praktyczne. Wyniki analiz można zastosować w dyskusji jako racjonalne argumenty na rzecz większej obecności wiary w humanistyce. 6. Implikacje społeczne. Wyniki analiz mogą odnosić się do pedagogów. 7. Oryginalność artykułu (nowa wartość, nowość). Artykuł jako pierwszy w dziejach pokazuje źródłowo i na przykładach koncepcję wiary i otwarcia na Boga u Stefana Szumana.

Słow a klu c zow e: Stefan Szuman (1889-1972), wiara, zaufanie, credo, filozofia bytu, metafizyka, etyka, filozofia kultury, natura człowieka, pedagogika, wiara i rozum, cnota, niecnota, ateizm, Uniwersytet Jagielloński, Kraków, sumienie, personalizm, prawa człowieka, chrześcijaństwo, kultura, człowiek, Bóg, Absolut, godność człowieka, Jan Paweł II (1978-2005), Karol Wojtyła (1920-2005), Zygmunt Mysłakowski (1890-1971), komunizm w Polsce 


\section{Bibliografia}

\section{Archiwalia}

Instytut Pamięci Narodowej - Komisja Ścigania Zbrodni przeciwko Narodowi Polskiemu - Oddziałowe Biuro Udostępniania i Archiwizacji Dokumentów w Krakowie, teczka S. Szumana, sygnatura: IPN Kr 010/5529.

\section{Publikacje}

Bartnik, Czesław, Zdzisław Chlewiński. „Fideizm”. W: Powszechna encyklopedia filozofii, t. 3: E-G, Andrzej Maryniarczyk (red. nacz), 427-429. Lublin: Polskie Towarzystwo Tomasza z Akwinu, 2002.

Czachowski, Kazimierz Stanisław. Obraz współczesnej literatury polskiej 1884-1933, t. 3: Ekspresjonizm i neorealizm. Lwów: P.W.K.S., 1936.

Flis, Łukasz [= Szuman, Stefan]. Drzwi uchylone. Warszawa: Księgarnia Hoesicka, 1933.

Nicieja, Stanisław S. Cmentarz Łyczakowski we Lwowie w latach 1786-1986. Wrocław: Zakład Narodowy imienia Ossolińskich, 1988.

Ostrowska, Krystyna. „Stefan Szuman - w setną rocznicę urodzin”. Przegląd Psychologiczny. Kwartalnik 2 (1989 [wyd. 1990]): 515-522.

Szuman, Stefan. Afirmacja życia. Lwów: Lwowska Biblioteczka Pedagogiczna, 1938. Seria: Licealna Biblioteczka Filozoficzna, t. 12.

Szuman, Stefan. „Instynkty u człowieka”. Kwartalnik Pedagogiczny. Organ Sekcji Pedagogicznej Stowarzyszenia Chrześcijańsko-Narodowego Nauczycielstwa Szkół Powszechnych 1 (1934): 1-27.

Szuman, Stefan. Natura, osobowość i charakter człowieka, przedmową opatrzyły Grażyna Czyżewicz, Zofia Skórzyńska. Kraków: Wydawnictwo WAM, Księża Jezuici, 1995.

Szuman, Stefan. Poważne i pogodne zagadnienia afirmacji życia. Katowice: Józef Nawrocki, 1947.

Szuman, Stefan. Psychologia wychowawcza wieku szkolnego. Podręcznik dla nauczycieli i studentów. Kraków: Wiedza. Zawód. Kultura. Księgarnia. Wydawnictwo. Skład Nut, 1947.

Szuman, Stefan. „Wstęp zasadniczy do zagadnień wychowania estetycznego”. Marchołt. Kwartalnik poświęcony sprawom literatury i kultury 3 (1936/1937): 305-330.

Thomae, Summa contra gentiles, I.

Zawodziński, Karol Wiktor. „Liryka”. Rocznik Literacki, 1933 [wyd. 1934]: s. 14-47.

Zawodziński, Karol Wiktor. Wśród poetów, oprac. Wanda Achremowiczowa, wstęp Jerzy Kwiatkowski. Kraków: Wydawnictwo Literackie, 1964.

\section{Netografia}

Jan Paweł II. Homilia na Placu Zwycięstwa, Warszawa, 2 czerwca 1979 roku (film, fragment), https://www.youtube.com/watch?v=A3eN9xMSuxc (dostęp: 9.03.2017).

Jan Paweł II. Homilia na Placu Zwycięstwa, Warszawa, 2 czerwca 1979 roku (tekst, fragment), http://www.zrodlo.krakow.pl/rocznik-2011/numer-18/czlowieka-nie-mozna-do-konca-zrozumiec-bez-chrystusa/ (dostęp: 9.03.2017). 